УДК 1751

https://doi.org/10.31548/philolog2020.01.108

\title{
POSTMODERNISM AS THE MANIPULATIVE TECHNOLOGY IN MODERN UKRAINIAN ADVERTISING: THE ARTISTIC DOMINANT CHARACTERISTIC
}

\author{
I. B. IVANOVA, Doctor of Philology, Associate Professor, \\ Simon Kuznets Kharkiv National University of Economics \\ E-mail:vlad-7@ukr.net \\ orcid.org/0000-0002-4786-4979 \\ O. P. LYSYTSKA, PhD in Philology, Associate Professor, \\ Yaroslav Mudryi National Law University \\ E-mail: elenalisitskaya74@ukr.net \\ orcid.org/0000-0001-6151-8696
}

\begin{abstract}
The article deals with the influence of the artistic element of the advertising message on the effectiveness of the commercial offer. Postmodernist aesthetics is presented as an important component of modern manipulative technologies in the world media. Contemporary advertising is presented as a high-tech art that is media oriented and focused on the emotional and image dominant element of the consumer audience. It determined the increased attention of advertisers to the philosophy and aesthetics of postmodernism. The techniques and methods that increase the effectiveness of the advertising message are explored. It is the use of the culture of laughter and innovative, creative and original verbal and non-verbal means of influence, which provide a postmodernist artistic approach to comprehending advertising images. The ways of depicting emotional and image elements that dictate the use of artistic creative methods in advertising discourse are presented.

Postmodernism is defined as artistic behavior that is effectively used in the modern advertising business. Rejection of reality is one of the ideological precepts of the aesthetics of postmodernism, the aesthetics of a high level of consciousness and intellectuality. Cultural mediocrity involves citing marked by a slight irony, joke, and grotesque. The main directions of development of postmodern advertising genres, the directions of formation "citing" of advertising image created in aesthetics of postmodernism are presented in the work.

It is stated that advertising created in postmodernist aesthetics makes the effect of fragmentation as one of the features. It is underlined that politics and language are the tools for targeting the audience, and the rejection of truth is the characteristics of postmodernist advertising. Intertextuality is defined effective in creating the effect of the unspoken providing the space for imagination to the consumer.
\end{abstract}

Key words: postmodernism, stylization, artistic method, manipulative technologies, advertising, ideology.

Introduction. In the early twentieth century, advertising ceased to be a technology of informing and began to acquire the status of art, media technology, aesthetics, and high-tech production. In fact, modern advertising significantly affects the artistic and aesthetic tastes of a person. That is why the problems of enhancing the impact of advertising, and also the correlative links between advertising and art, and the creative method and high technology, the artistic and social components, - are relevant and controversial, they cause much debate among professionals in the field of advertising and art. This fact defines the scientific novelty of the article.

Modern advertising is high-tech, mediaoriented and centered on the emotionalsensual field of a modern consumer. It has the great impact on the audience, using creative verbal and non-verbal means of influence. Emotional and image dominants in advertising texts determine the relevance

(C) I. B. Ivanova, O. P. Lysytska

«International journal of philology» | «Міжнародний філологічний часопис» Vol. 11, № 1, 2020 
of the study of the use of artistic creative methods in advertising discourse.

Postmodern creative expression is capable of generating high quality and effective advertising text through a number of criteria: verbal clarity, the effect of emotional "empathy", original reasoning, polemics, grotesqueness, expectation of trust, creating a sense of presence. Postmodernism intertextuality makes it possible to transform the quotation into a paraphrase, a slogan to a link, to achieve the edge effect, and most importantly, the effect of waiting for the realization of an unfulfilled dream.

Postmodernism in advertising production does not create its own "genre" canons, does not dictate the stylistics of the message, but becomes a form of creative production and creative behavior. It ensures the survival of the Ukrainian commercial text as a national socially-labeled product.

Modern advertising can meet the highest artistic and cultural standards of the world to remain competitive in the advertising market, and the art form in advertising continues to be used until it is effective and has exhausted the credit of consumer confidence.

Recent researches and publications. Modern research in the advertising field is presented in the range of works by scientists T. Gulak, I. Lysychkina, L.Pavlyuk, T. Primak, V. Zirka and others $[2 ; 10 ; 13 ; 15 ; 18]$. Researchers from different fields of science and specialists in advertising business considered the artistic and creative problems and the mechanisms of advertising communication, also the specificity of advertising discourse itself: manipulative techniques in advertising (V. Zirka, T. Khazagerov, I. Ivanova) [18; 7; 3]; pragmatics of advertising message (Yu. Korneva, I. Moiseenko, S. Seliverstov) [9; $11 ; 16]$; the linguostylistic aspect of an advertising text (N. Kohteva, D. Rosenthal, O. Kara-Murza) [8; 6]; syntax, structural and stylistic properties of the advertising texts (I. Moiseenko, T. Gulak) [11;2].

The determination of the functional and stylistic status of modern advertising text is important in the defined sphere. O. V. Protopopova and E. A. Bazhenova [1] hypothesized that advertising text is a contamination of different genres, styles, speech varieties of forms and genres (oral written, monologic - dialogical, etc.), which is caused by the use of different ways of argumentation (emotional, rational, associative, logical, figurative, etc.). Thus, the term "style hybridity" of the advertising text comes to usage; it is a matter of an absolutely new style. O. Kara-Murza [6] made a conclusion concerning the emergence of advertising style as a separate kind of modern advertising. Ye. Ivanova [4] considers the functional and pragmatic peculiarities of the use of speech game tools, taking the text of Englishlanguage banner advertising as the material for exploration. T. Primak [15] characterizes a wide range of artistic methods and artistic ideologies, in particular, at this stage of advertising development. The researcher characterizes postmodern advertising of the 2000s; it is the use of images of individual parts of the human body (eye, face, legs, hands) or objects (often this is what is advertised or should cause associations related to the advertised product) or parts of them [15]. B. Neroznak describes a typology of advertising text, based on the principles of the degree and intensity of associative influences [12].

The study of postmodernism characteristics of the modern text is introduced by

Y. Staltovna. The researcher notes the interpretability as a pivotal component of the postmodernism: “... reality comes only through our own interpretations of the individual perception of the world. Postmodernism considers the individual's particular life experience more than abstract principles, arguing that the outcome of each individual's experience will be necessarily unreliable and relative, rather than accurate and universal" [17, p. 210].

The purpose of the research is to identify the features of postmodernism as the artistic dominant characteristic, and the

(C) I. B. Ivanova, O. P. Lysytska

«International journal of philology» | «Міжнародний філологічний часопис» Vol. 11, № 1, 2020 
aesthetics of creating commercial advertising in Ukraine.

The goal set out in the paper defines the task: to determine the main directions of forming a "cited" advertising image created in the aesthetics of postmodernism; to distinguish the features of postmodernism as an artistic method in business.

Methodological background of the study. The research is based on a comprehensive approach. The article uses inductive, deductive methods, and a method of interdisciplinary research. We also take into account the possibilities of the interpretative methodology used in the research of the language material. These methods include the analysis of linguistic categories and speech scenarios of interpretation of the world as a way of thinking and metality.

For the study of advertising texts, descriptive and structural methods are used, as well as the component analysis of the words and images of advertising texts for outdoor advertising, advertising on social networks, in the subway and on employment sites.

The semantic-stylistic method, also used in this article, allowed us to analyze the language game, parody, grotesque and linguistic carnival, which make up the aesthetic and informative value of advertising texts which can be used for manipulative influence.

Results. A sign of society's willingness to live in the post-industrial world is the openness to the perception of advanced concepts, new styles, ways of thinking, and presentation of material. Advertising in Ukraine in the 21st century adopts the ideology of postmodernism as one of the semantic precepts of modern commercial advertising.

For the aesthetics of postmodernism as the aesthetics of a high level of consciousness and intelligence, relativism is important. Cultural indirectness implies quotation as a universal mixing of ideas, ideologies, styles and forms, marked by a slight irony, joke, grotesque, and so on. For example: Чac обирати МАТРАЦ. Свim мampauis. (Time to choose a MATTRESS. The world of mattresses).

Thus, advertising created in postmodernist aesthetics, makes the effect of fragmentation, there is an impression of compositional dissociation and the lack of symmetry and consistency in expression. It also has visual displays: letters of different sizes, colors, configurations. An effect of a multilevel advertising text appears; the artistic image is eclectically recognizable and new at the same time. For example: ЗЕ! Леніна. Переживемо цей день разом. Зеленіна краплі. (ZE! Lenin. Let's go through this day together. Zelenin drops.)

First, this advertisement appeared in the media space of Ukraine during the election period. Every Ukrainian citizen recognized a political message, divided into fragments, reworked due to the game with fonts and parts of words (ZE - the first syllable in the name of one of the candidates (V. Zelenskiy). Ze- prefix is used to name the candidate's team (ЗE!команда -ZE!team). Secondly, the advertisement is made in the aesthetics of this candidate's election posters, using corporate colors and fonts, containing its own advertising information. Thus, the fundamental principle of postmodernism is realized: the rejection of reality, as aesthetics guideline, is reflected in the advertisement Ze!Lenina drops, referring a non-existing realia to the popular name, creating new virtual reality and offering it to the public.

So, as we see, politics, language, and motivation to form beliefs and ideas are important for the postmodernism. Targeting the audience to the myth, recognizable and desirable, helps to accept changes in the message made by the new information; the "departure from the truth" is effective. Stereotyping reinforces the effect - today's audience perceives the world subjectively. Obviously, postmodernism helps to realize a number of advertising imperatives:

- Polycode imperative - the implementation of the "serial thinking" guidelines that characterize a modern person. For example, a series of clicks from 
Medtekhnika dedicated to the topic of election debates: Кадр 1. Трясутся ноги дойти до дебатов? У нас есть опора. Думай ...TE! Кадр 2: Медтехника / Одягай ... TE памперс... і марш на дебати! Памперси mym http... (Frame 1. Are your legs shaking to get to the debate? We have a support. Think... YOU! (Думай ...TE!) Frame 2: Medtekhnikal Wear ... YOU! (Одягай ... TE) diapers ... and march for debate! Pampers here http...). Here is the suffix-TE often used by one of the candidates in his video messages during election campaign.

- The behavioral virtue imperative: an increase in the level of quasi-reality, the perception of the simulation world as reality. This is a comprehensive approach where original design, symbolism of colors, font and size games are present. For example: Думай про природу та залиш після себе ЗЕлену планету. Спеціальна акція від EKOPANDA. ЗЕлена щітка / ПОРОШок для відбілювання. (Think of nature and leave behind a Ze-planet (ЗЕлену (green) планету). Special promotion from EKOPANDA. ZE-brush (Green)/ POROSHok - Bleaching Powder. Prefix 3E- is used to refer to the presidential candidate Volodymyr Zelenskiy and his team (Зе! Команда, Зе-политика, Зе-кандидаты - Ze!team, Ze-policy, Zecandidates). ПОРОШок (POROSHok) ironic use of part of the name of former President Poroshenko, that is a homonym of the word порошок (Eng. bleaching powder).

- The imperative of "transmitted" unification of behavior - the mass flow of information and the large number of possible sources of information lead to the need to create accessible, easy to understand and further assimilate texts. Example: Гарантирую снижение цен на интернет в 6 раз. Акция! Звони сейчас. (I guarantee a reduction in Internet prices by 6 times. Promotion! Call now). This is a slogan on price reductions offered by several presidential candidates. Such calls are used on a regular basis, they are easy to recognize, unify and perceive - that is why they are effective and are used in commercial advertising. Recognized imitation testifies to the postmodernist nature of the message.

The categories of inaccuracy and intertextuality in the image structure of the advertising message are manifested in creating the effect of the unspoken, which pushes the audience to certain conclusions, but is not final; there is always the space for independent second-guessing, finish-telling of the advertising product by the consumer. Thus, the promotional text becomes "his own" for the addressee. Example: Житлових комплексів багато. Новий "Автографр" ОДИН. (There are many residential buildings. The new "Autograph" is ONE). The revised slogan of one of the presidential candidates in the elections in the original sounded: Many candidates. The president is one. In this way, commercial advertising uses a hyped and familiar slogan from political advertising. The revised quotation acts as an artistic and stylistic technique, allowing one to finish telling his / her dream, to say this text, but with another commercial proposal.

The postmodernist aesthetics of the artistic image within the advertising text requires freedom for imagination, the release of the carnival effect and creativity of the consumer of advertising.

Conclusions. High technology and innovation in artistic approaches to advertising, ways of constructing a message push to a creative experiment as the main ideological aspect of postmodernism.

First of all, the creativity of postmodernism maintains the traditions of national art, eliminates the unnecessary and unjustified influences of the monotonous standards of Western advertising, thoughtless calquing and direct copying of foreign texts; it facilitates the moderate use of borrowings.

For all the differences in positions and interests, the participants in the production process of creating an advertising product should be equally interested in aesthetizing their communication environment, dialogue 
conditions, in the creativity and modernity of the advertising product.

Modern advertising text in Ukraine is a product of creation of a fundamentally new discourse type with its own set of manipulative technologies and artistic and technical norms. Postmodernist aesthetics, as a creative form of art, can inspire effective communication and is a universal tool for manipulating consumers' minds.

Artistic postmodernism in advertising encourages a lively dialogue with the consumer, since in today's post-industrial world one should not rely solely on marketing analysis.

\section{References}

1. Bazhenova, Ye. A., Protopopova, O. (2003). Yazyk i stil' reklamy. Stilisticheskiy entsiklopedicheskiy slovar' russkogo yazyka [Language and style of advertising. A stylistic encyclopedic dictionary of the Russian language]. Moscow: Flinta, pp. 635642. Available at: $h$ ttp://stylistics. academic.ru.

2. Gulak, T. V. (2004). Tsennostnyye struktury sovremennogo reklamnogo diskursa (na materiale rossiyskoy kommercheskoy i politicheskoy reklamy. Diss.kand. filol. nauk. [Value structures of modern advertising discourse (based on Russian commercial and political advertising) kand.philol.sci.diss]: Kharkov, $103 \mathrm{p}$.

3. Ivanova, I. B. (2016) Istoriya reklamy: movnostylistychnyy aspekt : monohrafiya [The history of advertising: the linguistic stylistic aspect]. Kharkiv : Vyd-vo Yurayt, $372 \mathrm{p}$.

4. Ivanova, Ye. S. (2014) Funktsional'no-pragmaticheskiye osobennosti ispol'zovaniya priyemnykh yazykovykh igr $v$ diskurse russkoyazychnoy bannernoy reklamy $v$ seti internet. Filologicheskiye nauki. Voprosy teorii i praktiki. Tambov: Gramota, № 3. Part 2. pp. 87-90. [Functional-pragmatic features of the use of language game techniques in the discourse of English-language banner advertising on the Internet]. Available at: www.gramota.net/materials/2/2014/32/24.html.
Modern Ukrainian advertising is steadily working on the creation of new and universally recognized imagery, new stereotypes and standards, close to the consciousness of a modern Ukrainian. After all, advertising must be responsive to social and artistic consumer demands in order to be effective. Therefore, we should avoid standards and clichés, and outdated stock of common things, and continue developing creative artistic traditions of the culture of popular laughter that shape advertising both as a productive industry, as a social product, and as an independent art.

5. Ilyin, I. P. (2001). Kul'turnoye podsoznatel'noye [Cultural subcon-scious]. Postmodernism. Moscow : INTRADA. pp.126-127.

6. Kara-Murza, E. S. (2014). Forms and genres of Russian commercial advertising. Medialinguistics. pp.28-32.

7. Khazagerov, G. G. (2002). Politicheskaya ritorika [Political Rhetoric]. Moskow : Nikkolo Media, 313 p.

8. Kohteva, N. N. (1997). Advertising: the art of the word: recommendations for creators of advertising texts. Moscow: Moscow State University Publishing House, $96 \mathrm{p}$.

9. Korneva, Yu. B. (1998). Kommunikativno-pragmaticheskiye i strukturno-semanticheskiye osobennosti yazyka sovremennoy frantsuzskoy reklamy. aref. diss.kand. filol. nauk [Communicativepragmatic and structural-semantic features of the language of modern French advertising. aref. kand. philol.sci.diss]. Kiev,16 p.

10. Lysychkina, I. O. (2005): Prosodychna orhanizatsiya anhlomovnoho dyskursu reklamy (eksperymental'no-fonetychne doslidzhennya na materiali brytans'koyi televiziynoyi reklamy) aref. diss.kand. filol. nauk. [Prosodic organization of Englishlanguage advertising discourse (experimentalphonetic study on the material of British television advertising) aref. kand. philol.sci.diss]. Kyiv, 19 p.

11. Moiseenko, I. P. (1996). Pragmalingvisticheskaya organizatsiya reklamnogo 
teksta: makro- i mikroanaliz (na materiale angloyazychnor bytovor reklamy): Diss.kand. filol. nauk. [Pragmalinguistics organization of the advertising text: macroand micro-analysis (based on the Englishlanguage consumer advertising) kand. philol. sci. diss]. Kyiv, $186 \mathrm{p}$.

12. Neroznak, V. P., Khaleeva, I. I. (2005). YAzykovaya lichnost' [Linguistic personality]. Effektivnaya kommunikatsiya: istoriya, teoriya, praktika: slovar'spravochnik. [Effective Communication: History, Theory, Practice: Dictionary]. Moscow : Olymp. pp. 587-591.

13. Pavlyuk, L. S. (2007). Ritorika, ideologiya, persuazivna komuníkatsíya [Rhetoric, ideology, persuasive communication]. Lviv : PAIS, $168 \mathrm{p}$.

14. Pocheptsov, G. G., Chukut, S. A. (2008). Ínformatsíyna polítika [Information Policy]: 2nd edition. Kiev: Knowledge, $663 \mathrm{p}$.

15. Primak, T. O. (2011). Stilí v oformlenní reklamnykh zvernen' [Styles in Advertising Design]: Ukraîna 2006-2010 Marketing i menedzhment ínnovatsíy. [Ukraine 2006-2010 Marketing and Innovation Management], 1, pp. 45-54. Available at: http://nbuv.gov.ua/jpdf/Mimi_2011_1_6.pdf.

16. Seliverstov, S. E. (2006). Sotsial'naya reklama. Iskusstvo vozdeystviya slovom [Social advertising. The art of influence by word]. Samara : Izdatel'skiy dom "Bakhrakh-M", 287 p.

17. Staltovna, Y. A. (2013). Postmodern yak metodolohichna dominanta linhvistychnykh studiy [Postmodern as a Methodological Dominant of Linguistic Studies]. Nova Filolohiya, 58, pp. 210-214. Available at: https://core.ac.uk/ download/ pdf/3369219.pdf.

18. Zirka, V. V. (2010). Manipulyativnyye igry $\mathrm{v}$ reklame [Manipulative games in advertising]. Moscow : Librocom, $256 \mathrm{p}$.

\section{ПОСТМОДЕРН ЯК МАНІПУЛЯТИВНА ТЕХНОЛОГІЯ В СУЧАСНІЙ УКРАЇНСЬКІЙ РЕКЛАМІ: МИСТЕЦЬКА ДОМІНАНТА}

\section{І. Б. Іванова, О. П. Лисицька}

Анотація. Стаття присвячена впливу мистецької домінанти рекламного повідомлення на ефрективність рекламної пропозиції. Постмодерна естетика представлена як важлива складова сучасних маніпулятивних технологій у медіа. Досліджено мистецькі прийоми та методи, що підвищують ефективність рекламного повідомлення, а саме: використання сміхової культури, звернення до творчих вербальних $і$ невербальних засобів впливу, котрі забезпечують постмодерний мистецький підхід. Представлено способи зображення емоційних та іміджевих настанов, що диктують використання мистецьких творчих методів у рекламному дискурсі.

Визначено, що відмова від реальності є однією з ідеологічних настанов естетики постмодернізму, який ефективно використовується в сучасному рекламному бізнесі. Виявлені особливі характеристики та ідеологічні константи постмодернізму, що впливають на ідеологічну складову та естетику реклами. У роботі представлено основні напрями розвитку жанрів постмодерної реклами, настанови фрормування «цитування» рекламного образу, створеного в естетиці постмодернізму. Наведено виконані у жанрі пародії на політичну та соціальну рекламу зразки комерційної реклами.

Ключові слова: постмодерн, стилізація, мистецький метод, маніпулятивні технології, реклама, ідеологія. 